\title{
MANAGING ACROSS GROUNDWATER AND SURFACE WATER: AN AUSTRALIAN 'CONJUNCTIVE LICENCE' ILLUSTRATION OF ALLOCATION AND PLANNING ISSUES
}

\author{
Imogen Fullagar $^{1}$ \\ Dr. Catherine Allan ${ }^{2}$ \\ Prof. Shahbaz Khan ${ }^{3}$
}

\begin{abstract}
Conjunctive use of groundwater is a common irrigation response to limited surface water availability. In the late 1970s, under a 'one resource policy', the New South Wales (NSW) government of Australia began issuing a form of conjunctive licence to irrigators with access to both surface water and groundwater. These licences were intended to provide the licence owners with the water supply security offered by conjunctive use. Institutional separation of groundwater and surface water prevented accounting across the resources. As a result the licences contributed towards over-allocation of groundwater. Conjunctive licences were subsequently discontinued and separated into surface water and groundwater components in the late 1990s. This paper explores the NSW experience of conjunctive licences in light of Australia's recent national agreement to manage connected surface water and groundwater as one resource. The conclusion is that flow systems cannot be allocated as 'one resource' if managed through independent groundwater and surface water planning institutions. Some implications and options for allocation across local water resources with hydraulic connectivity are considered.
\end{abstract}

\section{INTRODUCTION}

Freshwater flow systems are commonly comprised of both groundwater and surface water (Winter et al, 1998). In such systems, development of surface water will impact groundwater over time, and vice versa. These impacts are of increasing interest as demand for freshwater and sustainable management grows. Related issues include irrigation-induced salinity and declines in environmental

\footnotetext{
${ }^{1}$ Cooperative Research Centre for Irrigation Futures PhD candidate (Charles Sturt University). Postal address: c/o CSIRO Land and Water, GPO Box 1666, Canberra ACT 2601, Australia. Email: imogen.fullagar@csiro.au

${ }^{2}$ Environmental and Information Science Lecturer. Postal address: Charles Sturt University, PO Box 787, Albury NSW 2640, Australia. Email: callan@csu.edu.au

${ }^{3}$ Research Director (CSIRO) and Professor of Science and Technology (Charles Sturt University). Postal address: Charles Sturt University, Locked Bag 588, Wagga Wagga NSW 2678, Australia. Email: skhan@csu.edu.au
} 
health. Utilisation of system function and system accounting are central themes to related discussion (Qureshi et al 2002, Blomquist et al 2004).

The Australian priority of water management has been driven by a climate characterised by highly variable rainfall. This status has seen Australia active in the investigation of groundwater-surface water interaction and management (Braaten and Gates, 2003; Khan et al, 2003; Fullagar 2004; Evans et al 2005).

In Australia, the seven State governments maintain independent constitutional authority for water legislation and management within their respective jurisdictional boundaries. These States are federated under a national Australian Government. While the Australian Government has no direct responsibility for water management, it has had a key role in coordinating agreement and delivery of national water agendas (Tisdell et al, 2002) - a role supported by international responsibilities and economic leverage allowed through the Commonwealth of Australia Constitution Act (1900).

The most recent of such agendas is the National Water Initiative (Council of Australian Governments (COAG), 2004) which outlines national water industry objectives for the period 2004 to 2014 . The National Water Initiative includes in its objective:

"recognition of the connectivity between surface and groundwater resources and connected systems managed as a single resource" (pg 4; COAG, 2004).

This objective begs the question of how to allocate groundwater and surface water as a single resource within a connected system.

This paper outlines an unsuccessful attempt by the Australian state of NSW to allocate across groundwater and surface water via a form of conjunctive licence. This effort is analysed for institutional lessons of general relevance to water management.

\section{THE NSW CONJUNCTIVE LICENCE CASE STUDY}

\section{Data sources}

The NSW Department of Natural Resources is responsible for water licensing in NSW, however licensing is issued through regional centres. Departmental structure and records have been subject to two major restructures between 2002 and 2005. There is no known compilation of the history of NSW conjunctive licences. Information relating to the experience is therefore patchy and heavily dependent on corporate knowledge. 
Information for this case study was sourced through discussion with departmental officers (see acknowledgements), and a review of records these officers maintained for personal reference.

\section{Background}

Prior to the 1980s, NSW allocated water in the form of perpetual irrigation licences on the basis of land area rather than by volume (Taylor et al, 2001). Under these arrangements, surface water and groundwater licences were issued on the basis of demand and distinguished by associated infrastructure works. Irrigation licences were predominantly surface water licences.

By the mid-1970s, over-allocation of surface water became increasingly evident as land was developed for irrigation and associated water rights realised (Haisman, 2005). Naturally high variability of surface water availability also limited security for irrigation development. However, developers had invested on the understanding that area based water rights could be realised. A call for resolution of the discrepancy between allocated surface water and available surface water began radiating from nodal regions, notably the Namoi and Lachlan Valleys to the north of the State. Both public and private sectors looked to groundwater as a potential solution.

\section{$\underline{\text { Nature of conjunctive licences }}$}

NSW conjunctive licences were bore (groundwater) licences issued with a conjunctive condition. Under the conjunctive condition, the allocation of the licence was inversely dependent on seasonal surface water availability: the lower surface water availability, the more groundwater the licence would allow to be accessed. The conjunctive condition was accompanied by a scale factor which dictated the conversion scale through which groundwater allocation was calculated. This conversion ratio was originally $1: 1$, but adapted to try and account for local impacts such as declines in groundwater tables. (This paper focuses on the principles of the NSW conjunctive licence system and does not further consider the detail of these ratio changes).

Thus in areas where conjunctive licences were issued, two types of groundwater allocations existed:

1. standard groundwater licence (a fixed allocation as required by irrigators who were wholly groundwater dependent), and

2. conjunctive licences (for which allocation varied in response to annual surface water allocation). 


\section{Where and when conjunctive licences were issued}

Conjunctive licences were first issued in the Lachlan in 1976. The practice was subsequently extended to the across the northern irrigation areas of Namoi, Gwydir, and Border Rivers. In 1979, the issuing of conjunctive licences was adopted under a 'one resource' policy which sought to realise the drought security potential offered by groundwater resources (Department of Land and Water Conservation, 1997).

In the mid-1980's, land area based water rights were converted to volumetric licences (Taylor et al, 2001). During this conversion, the conjunctive condition was applied as a matter of course to bore licences owned by landholders with surface water rights. This resulted in the issue of conjunctive licences being extended to areas including the Macquarie, Cudgegong Valley, Murrumbidgee, and the lower Murray. Records exist for 94 conjunctive licences in the lower Murray, and over 300 conjunctive licences are believed to have been issued in the Namoi Valley. The Namoi Valley is recognised as having had the greatest concentration of conjunctive licences. On this basis it is estimated the number of conjunctive licences issued across NSW was in the order of 1000 .

\section{Institutional issues and separation of conjunctive licences}

NSW institutions treat groundwater and surface water as conceptually independent resources. This practice reflects the dominance of surface water demand in water development, and is a logical extension of differences in aquifer and surface storage attributes and infrastructure works required for access (Turral and Fullagar, 2006).

In accordance with the National Strategy for Ecologically Sustainable Development (COAG, 1992), NSW water management aims to:

1. maximise the economic return from available resources, and

2. (for renewable resources) define availability through sustainable limits.

NSW institutions have seen these objectives applied consistently but independently to surface water and groundwater. As result, surface water plans are therefore encouraged to fully account the development of a resource with highly variable availability, while groundwater plans are designed to fully account the development of a resource with stable availability.

Under conjunctive licences, surface water allocation which was unmet in years of low rainfall (see Figure 1a) became groundwater allocation. This resulted in the variable allocation of groundwater - a resource with stable availability (see Figure 1b). 


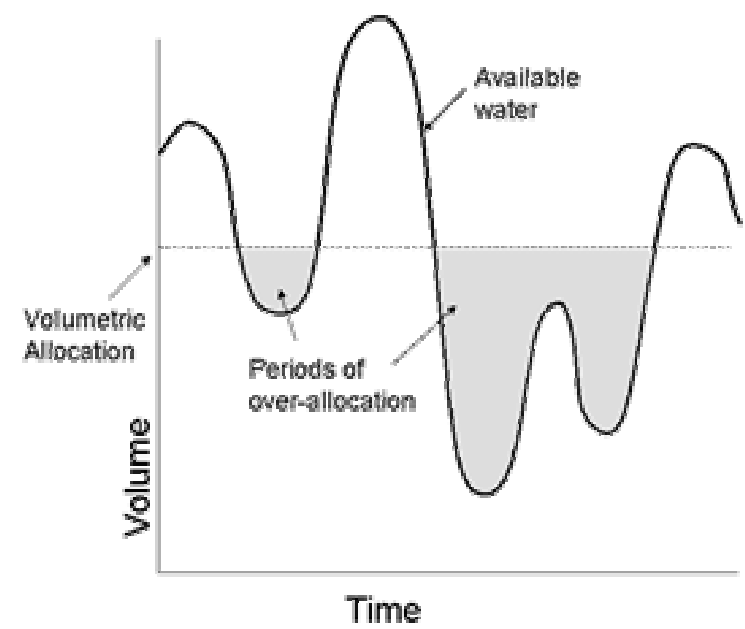

Figure 1a: Surface water allocation and availability

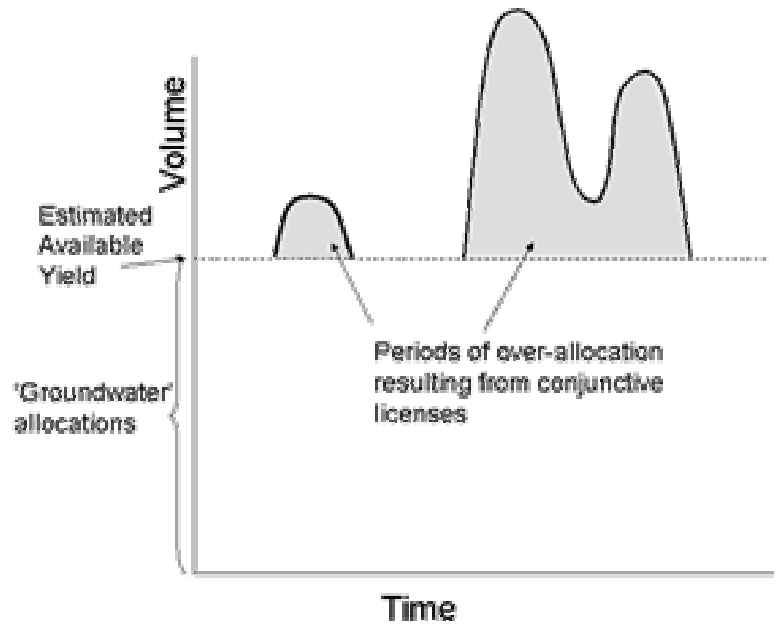

Figure 1b: Impact of surface water availability on groundwater demand under conjunctive licences

This variability could be accommodated by either setting groundwater allocation limits on the basis of a maximum estimate of conjunctive demand (Figure 2a), or accepting periodic over-allocation and under-allocation of groundwater (Figure $2 b)$. 


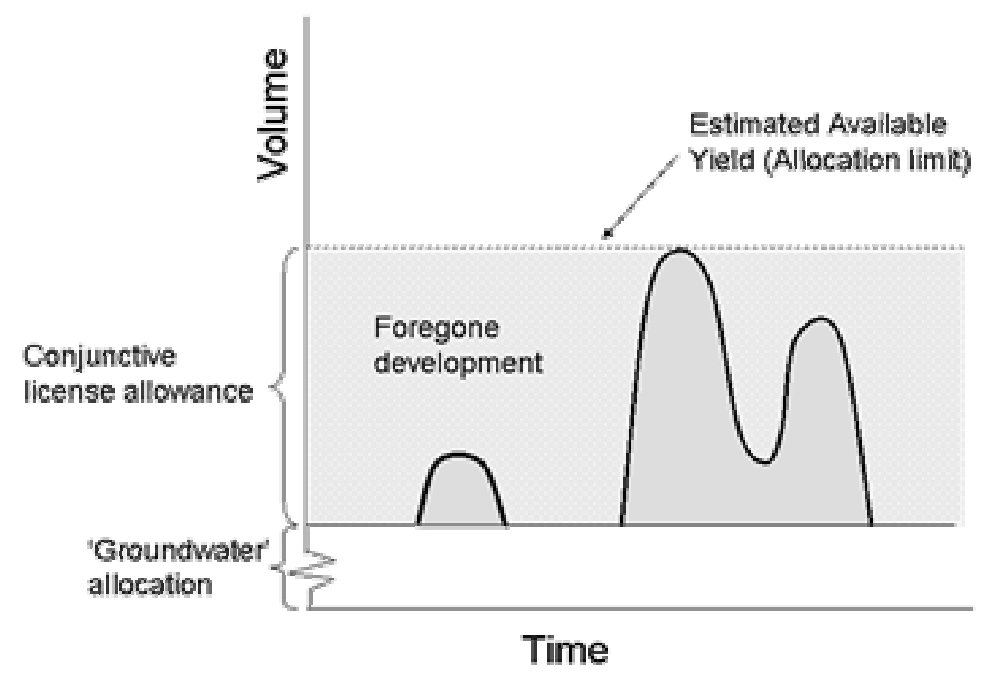

Figure 2a: Effect of allocating groundwater with full allowance for conjunctive demand

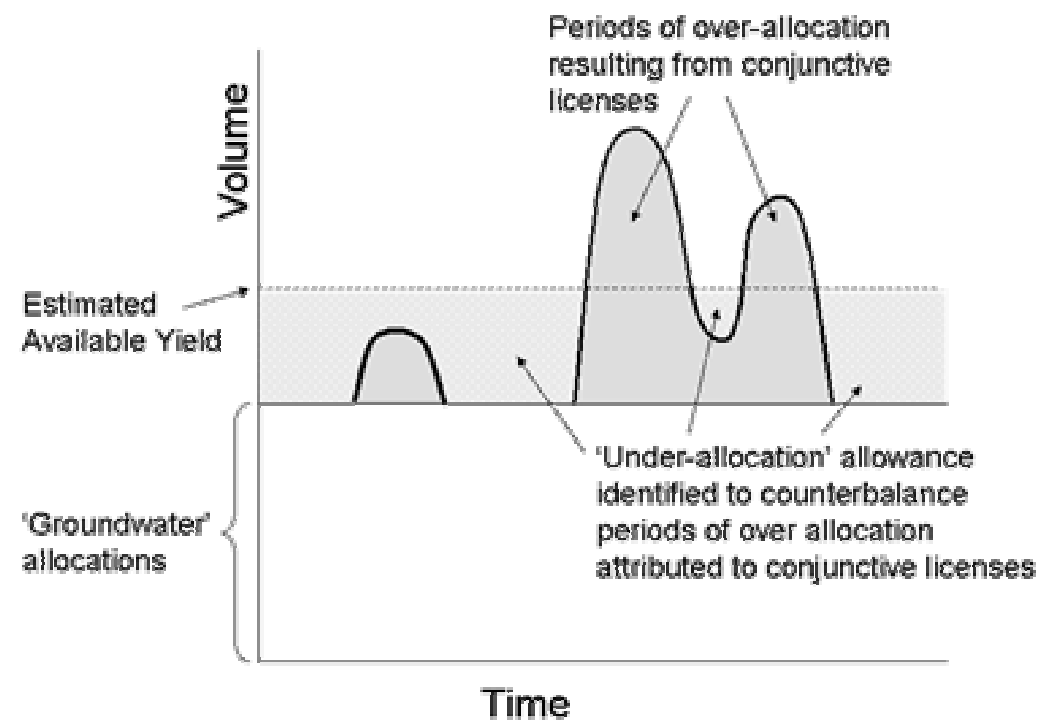

Figure 2b: Effect of allocating groundwater with partial allowance for conjunctive licences

The option illustrated in Figure 2a would result in underutilisation of available groundwater, which contradicted maximum economic return of groundwater. The option illustrated in Figure $2 \mathrm{~b}$ contradicted sustainability policies by allowing for over-allocation (which would increase with any long term decline in surface water availability). 
In both options, the protection of conjunctive users was absorbed by groundwaterdependent irrigation through either unrealised development (Figure 2a) or lost resource security (Figure $2 b$ ).

In recognition of these inconsistencies, the NSW government decided to discontinue conjunctive licences in the late 1990s (Gates and O'Keefe, 1999). Most conjunctive licences have since been separated into independent groundwater and surface water components.

\section{$\underline{\text { Subsequent institutional developments }}$}

The decision to separate conjunctive licences into groundwater and surface water components reinforced the practice of managing groundwater and surface water resources as institutionally independent entities. This practice has been cemented through progressive enactment of the NSW Water Act 2000. The "water sharing plans' underpinning this Act are typically distinguished as 'regulated water sharing plans', 'unregulated water sharing plans', or 'groundwater sharing plans' (see Figure 3). Where this has not been the case (eg Department of Infrastructure Planning and Natural Resources, 2003) groundwater and surface water allocation limits are independently specified within the plan.

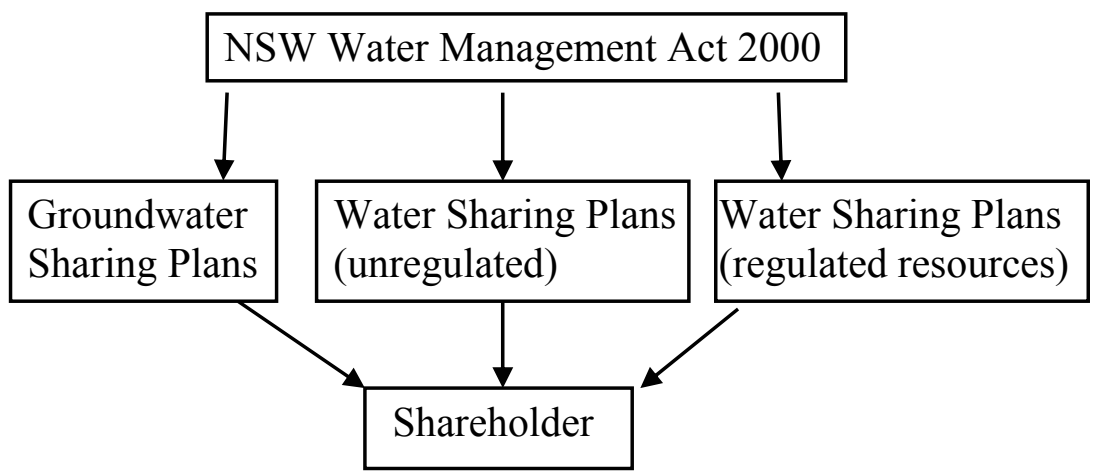

Figure 3: Water Management under the NSW Water Management Act 2000

The NSW Water Act 2000 requires the conversion of water licences from volumes to shares of the water resource specified within a water sharing plan. Within the share structure, all allocations covered by surface water plans are shares in a surface water resource, and all allocations covered by groundwater sharing plans are shares in a groundwater resource.

Table 1 uses the example of water sharing plans applicable to Coleambally (a NSW irrigation area within the Murrumbidgee catchment) to illustrate the discrepancies parallel but independent groundwater and surface water institutions create between local groundwater and surface water shares. Most notably: volumetric conversion of groundwater and surface water shares occurs through independent availability announcements. A local groundwater share therefore does not have the same volumetric value as a local surface water share. Water 
management opportunities for the different resources are further separated by independent carry-over and trade opportunities.

Table 1. Institutions for surface water and groundwater in Coleambally

\begin{tabular}{|c|c|c|}
\hline & Surface water & Groundwater \\
\hline Act & \multicolumn{2}{|c|}{ NSW Water Management Act 2000} \\
\hline Relevant Plan & $\begin{array}{l}\text { Water Sharing Plan for the } \\
\text { Murrumbidgee Regulated } \\
\text { River Water Supply } \\
\text { (Department of } \\
\text { Infrastructure Planning and } \\
\text { Natural Resources 2003) }\end{array}$ & $\begin{array}{l}\text { Water Sharing Plan for the } \\
\text { Lower Murrumbidgee } \\
\text { Groundwater Sources } \\
\text { (Department of Infrastructure } \\
\text { Planning and Natural } \\
\text { Resources, deferred) }\end{array}$ \\
\hline Entitlements secured as & \multicolumn{2}{|c|}{ Shares of resource defined by plan } \\
\hline Shares converted to volume by & \multicolumn{2}{|c|}{ Allocation } \\
\hline Availability announced & $\begin{array}{l}\text { Monthly (fortnightly in peak } \\
\text { season) with annual } \\
\text { prediction. }\end{array}$ & $\begin{array}{l}\text { Annually. An estimation of } \\
\text { annual sustainable yield is } \\
\text { provided and forms the basis } \\
\text { of the } 10 \mathrm{yr} \text { plan. }\end{array}$ \\
\hline Annual carry-over capacity & $15 \%$ of allocation & $50 \%$ of allocation \\
\hline Trade potential & $\begin{array}{l}\text { - Within water resource } \\
\text { defined by plan } \\
\text { - } \text { Between NSW water } \\
\text { resources on a common } \\
\text { river system } \\
\text { - Between States which } \\
\text { the river system crosses }\end{array}$ & $\begin{array}{l}\text { Within water resource } \\
\text { defined by plan (may be } \\
\text { restricted to local impact } \\
\text { 'zones') } \\
\text { - It is possible sell out of an } \\
\text { over-allocated plan, but } \\
\text { this requires creation of a } \\
\text { buying market in } \\
\text { developing areas }\end{array}$ \\
\hline
\end{tabular}

These arrangements make it difficult to equate local groundwater shares with local surface water shares, even where these property rights apply to hydraulically interdependent resources. This institutional context is a challenge for the management of connected systems as a single resource (Objective 23(x), COAG, 2004).

\section{DISCUSSION}

The NSW Water Sharing Plans consider and make provisions for environmental needs. Groundwater sharing plans are required to make environmental allocations as necessary to protect identified groundwater dependent ecosystems, including dependent surface flows. Surface water sharing plans are required to consider instream and terrestrial environmental needs. However within these plans, aquifer recharge is generally not considered or managed as a stream dependency, but as a component of transmission or unaccounted 'losses'. System water accounts by Khan et al (2003) clearly demonstrate the importance of water exchanged between surface and underground components of a flow system, and water truly 'lost' from that system (eg by evaporation). 
The 10 year timeframe of the NSW Water Sharing Plans seeks to strike a balance between the competing objectives of water property right security (ie through clear articulation of priority commitments such as the environment) and adaptive management. Independent plans means that within the 10 year span of these plans, groundwater and surface water availability are not designed to be responsive, even where these resources are hydraulically connected. Mechanisms for response under the NSW structure are by changing annual groundwater allocation, changing fortnightly surface water allocation, or changing long term allocations via the water sharing plans.

These options have capacity to respond to changes in water availability which can be attributed to development of adjacent resources, however they do not provide for proactive management of connectivity as might be allowed by active management of aquifer storage. This inflexibility could prevent the full potential productivity of water resources from being realised where it was feasible to overdraw and refill aquifer stores through conjunctive management of local groundwater and surface water systems.

Practical options allowed within the structure of water sharing plans include limiting the distance between bores and streams (Department of Land and Water Conservation, 2002). Evans, Dudding and Holland (2005) have further developed this concept, proposing groundwater allocation be accounted as a function of surface water through zones based on geology, distance from surface water flows, temporal displacement of impact, and managed temporal access to groundwater. This option protects the integrity of existing groundwater and surface water allocation institutions, but involves costs of groundwater access and trade constraints within the defined zones.

The NSW conjunctive licensing experience suggests that the allocation of groundwater and surface water as a single resource is dependent on a more fundamental reconciliation of groundwater and surface water planning and accounting.

Management across groundwater and surface water has been observed to be simple in concept, but difficult in practice (Qureshi et al, 2002). The NSW conjunctive licence experience illustrates constraints may be institutional as well as hydraulic where independent groundwater and surface water allocation regimes have been adopted.

Allocation of common shares across local groundwater and surface water components is not an easy option. The development of management arrangements requires clear definition of clear resource boundaries (Ostrom, 1992). Without such boundaries, it is difficult to separate management impacts from third party impacts. Boundary definition is a nontrivial task for groundwater-surface water resources, because groundwater boundaries can 
transcend topographical catchments (typically used to bound surface water resources).

Furthermore, surface water tends to be the preferred resource where it is available. To protect environmental allocations, a 'one resource' share allocation system would therefore need to limit the realisation of shares as surface water. A similar framework for the geographic distribution of groundwater accessions would be required to prevent foci of over-draw.

A common share approach may also limit capacity to effectively address issues specific to groundwater or surface water. These could include issues of water quality, mobilisation of soil salts, maintenance of infrastructure standards, and management for specific environmental objectives.

Finally, under a common share approach, all local water shares would have similar relevance to the water trading market. Existing water trading markets are established on flow attributes and regulation of river or aquifer systems.

Consistency of local water shares would not make this distinction, and therefore be inconsistent with regional water markets. This could significantly compromise the economic opportunities which exist where local water shares can be traded on a larger market.

\section{CONCLUSION}

The key conclusion to be drawn from the NSW conjunctive licence experience is that flow systems cannot be allocated as 'one resource' if managed through independent groundwater and surface water planning institutions. The experience also suggests that local allocation mechanisms must be consistent with broader scale allocation mechanisms if trading opportunities are to be retained.

Concern for future river flows is currently driving groundwater policy agendas in Australia. Australian governments are therefore increasingly looking to integrate groundwater and surface water management. All management options must address the reality that water is a limited resource. The challenge is full evaluation and accounting of the benefits and costs of different options, while accounting for differences between sites and communities. These benefits and costs may be resource specific, but they may also relate to costs and benefits of property right management options such as trade. In developing an appropriate range of options, Australia is advantaged by common political, social and hydraulic incentives for improving management across groundwater and surface water. 


\section{ACKNOWLEDGEMENTS}

The authors would like to acknowledge and thank the following officers of the NSW Department of Natural Resources for assistance in compilation of the conjunctive licence history and institutional context: George Gates (also chair of Australia's National Groundwater Committee), Liz Webb, Steve Webb, and Mohommed Alamgir.

\section{REFERENCES}

Blomquist W, Schlager E, Heikkila T (2004). Common Water, Diverging Streams. Resources for the Future, Washington DC.

Braaten R and Gates G (2003) 'Groundwater-surface water interaction in inland New South Wales: a scoping study', Water Science Technology, vol 48(7), pp. 215-24

Council of Australian Governments (1992) National Strategy for Ecologically Sustainable Development. Available online at www.deh.gov.au/esd/national/nsesd/index.html

Council of Australian Governments (2004) Intergovernment Agreement on a National Water Initiative. Available online as "NWI Agreement" at www.nwc.gov.au/NWI

Department of Infrastructure Planning and Natural Resources (2003) Water Sharing Plan for the Dorrigo Plateau Surface Water Source and the Dorrigo Basalt Groundwater Source. NSW Government, Sydney. Available online at: www.dnr.nsw.gov.au/water/sharing

Department of Infrastructure Planning and Natural Resources (2003) Water Sharing Plan for the Murrumbidgee Regulated River Water Supply. NSW Government, Sydney. Available online at: www.dnr.nsw.gov.au/water/sharing

Department of Infrastructure Planning and Natural Resources (deferred) Water Sharing Plan for the Lower Murrumbidgee Groundwater Sources. NSW Government Sydney. Available online at: www.dnr.nsw.gov.au/water/sharing

Department of Land and Water Conservation (1997) Groundwater Management Area 011 (Upper Lachlan) - Groundwater Management Policy 1997 - 2002. NSW Government, Sydney.

Department of Land and Water Conservation (2002) The NSW State Groundwater Dependent Ecosystems Policy. NSW Government, Sydney. 
Evans R, Dudding M, Holland G (2005) River-groundwater interaction, a practical management approach. Paper presented at $29^{\text {th }}$ Hydrology and Water Resources Symposium, 21-23 February 2005, Engineers Australia, Canberra.

Fullagar, I (2004) Rivers \& aquifers: towards conjunctive water management (workshop proceedings). Bureau of Rural Sciences, Canberra. Available as free download by following Bureau of Rural Science link on www.daff.gov.au/content/publications.cfm

Gates G and O'Keefe V (1999) Sustainable groundwater management in NSW, Australia. In proceedings of the Murray-Darling Basin Groundwater Workshop, Griffith NSW, 14-16 September, pp 35-41.

Haisman B (2005) Impacts of water rights reform in Australia. Chapter 5 in: Bruns BR, Ringler C and Meinzen-Dick R (Eds) Water Rights Reform: Lessons for Institutional Design. International Fool Policy Research Institute, Washington DC

Khan S., Beddek R, Blackwell J, Carroll J, Tariq R and Paydar Z. (2003) Whole of Catchment Water and Salt Balance to Identify Potential Water Saving Options in the Murrumbidgee Catchment. Consultancy Report for Pratt Water Initiative in the Murrumbidgee catchment.

Ostrom E (1992). Crafting institutions for self-governing irrigation systems. San Francisco: Institution of Contemporary Studies.

Qureshi AS, Bhatti A, Jehangir WA (2002) Managing Surface and Groundwater Resources: Proceedings of the International Workshop on Conjunctive Water Management for Sustainable Irrigated Agriculture in South Asia. Lahore: International Water Management Institute.

Taylor P, McGlynn T, and Martin W (2001) The influence of privatisation on irrigation water rights in NSW. Paper presented at the Regional Conference of the International Association for the Study of Common Property. Brisbane, Australia, September 2001.

Tisdell J, Ward J, and Grudzinski T (2002) The development of water reform in Australia. Technical Report 02/05. Cooperative Research Centre for Catchment Hydrology. Monash University, Melbourne.

Turral, H and Fullagar I (2006). Institutional directions in groundwater management in Australia. Chapter 15 in The Agricultural Groundwater Revolution: Opportunities and Threats to Development. CABI Publishing (in press)

Winter TC, Harvey JW, Franke OL and Alley WM (1998) 'Groundwater and surface water: a single resource'. Circular 1139, US Geological Survey, Denver Colorado 